suppressed after only one month's treatment. ${ }^{12} \mathrm{We}$, however, found that the inhibition of bone resorption is temporary and that control of the disease needs repeated courses of treatment.

The precise mechanism causing the mineralisation defect is not known but was unrelated to changes in $1,25(\mathrm{OH})_{2}$ vitamin $\mathrm{D}$ in this study. Possible side effects of sodium etidronate include interference with alkaline phosphatase activity, reduced synthesis of proteoglycans, and a toxic effect on bone cells. ${ }^{14}$

In conclusion, sodium etidronate $20 \mathrm{mg} / \mathrm{kg} /$ day results in a biochemical improvement in Paget's disease when given for as short a period as two to four weeks, but it produces a mineralisation defect and the effect on bone resorption is not permanent. Although the defect in mineralisation spontaneously corrects when treatment is stopped we doubt whether any manipulation of the dose or duration of treatment can dissociate the drug's beneficial effects on resorption from its adverse effects on mineralisation. It is not, therefore, ideal for long term management of patients with Paget's disease.

\author{
References \\ 1 Smith R, Russell RGG, Bishop MC, Woods CG, Bishop M. Paget's disease of bone. Q J Med \\ 1973;42:235-56
}

2 Russell RGG, Smith R, Preston C, Walton RJ, Woods CG. Diphosphonates in Paget's disease. Lancet 1974; i:894-8.

3 Khairi MRA, Meunier P, Edouard C, et al. Quantitative bone histology in Paget's disease of bone: influence of sodium etidronate (EHDP) therapy. Calcified Tissue Research 1977;22(suppl): 355-8.

4 Khairi MRA, Altman MD, DeRosa GP, Zimmerman J, Schenk RK, Johnston CC. Sodium etidronate in the treatment of Paget's disease of bone. Ann Intern Med 1977;87:656-63.

5 Boyce BF, Smith L, Fogelman I, Johnston E, Ralston S, Boyce IT. Focal osteomalacia due to lowdose diphosphonate therapy in Paget's disease. Lancet 1984; ;:821-4.

6 Kanis JA, Evanson JM, Russell RGG. Paget's disease of bone: diagnosis and management. Metab Bone Dis Relat Res 1981;3:219-30.

7 Hodgkinson $A$, Thompson $T$. Measurement of the fasting urinary hydroxyproline:creatinine ratio in normal adults and its variation with age and sex. F Clin Pathol 1982;35:807-11.
ing

8 Taylor GA, Peacock M, Pelc B, Brown W, Holmes A. Purification of plasma vitamin D metabolites for radioimmunoassay. Clinica Chimica Acta 1980;108:239-46.

9 Aaron JE, Makins NB, Francis RM, Peacock M. Staining of the calcification front in human bone, using contrasting fluorochromes in vitro. F Histochem Cytochem 1984;32:1251-61.

10 Aaron J. Histological methods. In: Nordin BEC, ed. Calcium phosphate and magnesium metabolism. Edinburgh: Churchill Livingstone, 1976:564-8.

11 Walton RJ, Russell RGG, Smith R. Changes in renal and extrarenal handling of phosphate induced by sodium etidronate (EHDP) in man. Clinical Science and Molecular Medicine 1975;49:45-56.

12 Preston CJ, Yates AJP, Beneton MNC, et al. Effective short term treatment of Paget's disease with oral etidronate. Br Med f 1986;292:79-80.

13 Siris ES, Canfield RE, Jacobs TP, Stoddard KE, Spector PJ. Clinical and biochemical effects of EHDP in Paget's disease of bone: patterns of response to initial treatment and to long-term EHDP in Paget's disease of bone: patterns of re
therapy. Metab Bone Dis Relat Res 1981;3:301-8.

14 Plasmans CMT, Jap PHK, Kuigars W, Stoof TJJH. Influence of a diphosphonate on the cellular aspect of young bone tissue. Calcif Tissue Int 1980;32:247-56.

Accepted 4 March 1986

\title{
Deficiency of thiosulphate sulphurtransferase (rhodanese) in Leber's hereditary optic neuropathy
}

\author{
C J M POOLE, P R N KIND
}

\begin{abstract}
Leber's hereditary optic neuropathy is a rare cause of progressive visual failure. Its cause is unknown, but one hypothesis is that patients have a defect in the detoxication of cyanide. One of the enzymes used in this detoxication is thiosulphate sulphurtransferase (rhodanese). The activity of this enzyme was measured in the rectal mucosa of a group of subjects with Leber's hereditary optic neuropathy, and it was found to be considerably reduced compared with that in a group of controls $(p<0.001)$. This finding supports the hypothesis of an inborn error of cyanide detoxication in this condition.
\end{abstract}

\section{Introduction}

In 1965 Wilson showed that plasma and urinary thiocyanate concentrations were lower in a group of smokers with Leber's hereditary optic neuropathy than in a control group without this neuropathy. ${ }^{1}$ This and the finding of raised plasma cyanocobalamin concentrations in these patients ${ }^{2}$ led to the hypothesis that there is an inborn error in cyanide detoxication in patients with Leber's hereditary optic neuropathy. ${ }^{3}$ Another hypothesis is that Leber's

\footnotetext{
Departments of Neurology, Medical Ophthalmology, and Chemical Pathology, St Thomas's Hospital, London SE1 7EH

C J M POOLE, MB, MRCP, neurology registrar

PR N KIND, PHD, FRCPATH, top grade biochemist

Correspondence to: Dr C J M Poole, Medical Unit, Westminster Hospital, London SW1P 2AP.
}

hereditary optic neuropathy is a hereditary vascular neuroretinopathy. ${ }^{4}$

The main detoxication route for cyanide is the enzymic transfer of sulphur from thiosulphate (or mercaptopyruvate) to cyanide to form thiocyanate. Wilson found no difference in the activity of thiosulphate sulphurtransferase (rhodanese; EC 2.8.1.1) in liver samples taken at necropsy of two patients who had had Leber's hereditary optic neuropathy compared with samples from controls.' In 1981, however, Cagianut et al reported reduced activity of liver rhodanese in two patients with Leber's hereditary optic neuropathy compared with living and dead controls.

Rhodanese is an intramitochondrial enzyme and therefore may be found in most tissues; it occurs in large quantities in the liver and kidneys. For ethical and practical purposes rectal mucosa was chosen as the source of specimens for our enzyme assays. We compared the activity of rectal mucosa rhodanese in subjects with Leber's hereditary optic neuropathy with that in control subjects. In addition, rhodanese activity was measured in liver and rectal mucosa obtained at necropsy from controls.

\section{Patients and methods}

Ten white men with Leber's hereditary optic neuropathy from nine different families living in southern England were studied. All had optic atrophy that was inherited matroclinically and fulfilled the criteria of the diagnosis of Leber's hereditary optic neuropathy described by Lundsgaard ${ }^{6}$ -namely, a predominantly male affection with acute or subacute bilateral visual loss with central scotomas. At least one subject on the maternal side of each pedigree had been similarly affected. Control specimens were obtained from 12 white patients (seven men, five women) undergoing investigations for various bowel disorders such as carcinoma, colitis, and idiopathic diarrhoea ("diseased" controls) and from 20 white patients ( 17 men, three women) undergoing routine colonoscopy for colonic polyps ("healthy" controls). Three doctor volunteers also acted as "healthy" controls. Rectal 
mucosa was obtained by the usual technique of sigmoidoscopy or colonoscopy with biopsy forceps. Postmortem rectal mucosa and liver samples were taken from cadavers with non-neuro-ophthalmic disease at St Thomas's Hospital, London.

Specimens were stored at $-20^{\circ} \mathrm{C}$ for up to one month until assayed. Known weights of tissue were homogenised in ice cold glycine $(0 \cdot 1 \mathrm{~mol} / \mathrm{l})$ using a microtissue grinder and then centrifuged at $3000 \mathrm{rpm}$ for 30 minutes at $4^{\circ} \mathrm{C}$. A $5-30 \mathrm{mg}$ sample of wet tissue was used to make a final homogenate volume of 400-1000 $\mu \mathrm{l}$. After centrifugation $50, \mu \mathrm{l}$ of the clear supernatant was used to measure rhodanese activity by the method of Sorbo. ${ }^{7}$ Volumes of reagents were scaled down by a factor of 10 to provide a micromethod, thereby using less of the potentially hazardous cyanide solution and also accommodating the smaller sample volume. Samples were incubated at $37^{\circ} \mathrm{C}$ for 20 minutes. A blank tube was set up for each test sample in which all reagents were present. These were incubated for the same time, but the tissue extract was added after the addition of the formaldehyde, which was used to stop the enzyme reaction. A further $50 \mu$ of the supernatant was used to measure protein concentration by the Ponceau S-trichloracetic acid micromethod. ${ }^{8}$ Enzyme activity was expressed as $\mu$ mol thiocyanate/g protein $/ \mathrm{min}$.

A two tailed Mann-Whitney test was used to compare subjects with Leber's hereditary optic neuropathy with healthy and diseased controls.

\section{Results}

Mean age of the subjects with Leber's hereditary optic neuropathy was 39 (range 22-58) years. The duration of optic atrophy varied from six months to 24 years. We considered this group to be representative of patients with Leber's hereditary optic neuropathy. Mean ages of the healthy and diseased controls were $61(30-89)$ years and $54(33-79)$ years, respectively.

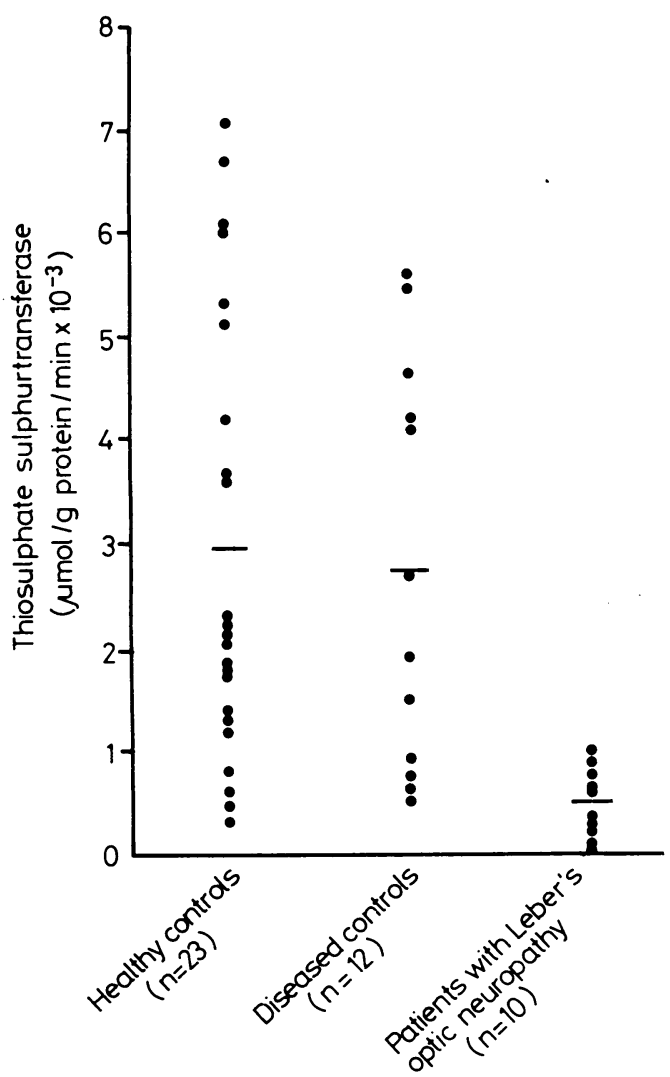

Thiosulphate sulphurtransferase (rhodanese) activity in subjects with Leber's hereditary optic neuropathy and diseased and healthy controls.

The figure shows the results of rhodanese assay in rectal mucosa. There was a significant difference between the mean (SEM) enzyme activity for healthy controls (2928 (447) $\mu \mathrm{mol}$ thiocyanate/g protein $/ \mathrm{min})$ and for subjects with Leber's hereditary optic neuropathy (480 (108) $\mu \mathrm{mol}$ thiocyanate $/ \mathrm{g}$ protein $/ \mathrm{min})(\mathrm{p}<0.001)$ and also between diseased controls $(2738$ (563) $\mu \mathrm{mol}$ thiocyanate/g protein/min) and subjects with Leber's hereditary optic neuropathy $(p<0.001)$. In both control groups there was no relation between sex, age, weight of biopsy specimen, duration of storage, and enzyme activity. The intra-assay precision varied by less than $5 \%$. Supernatant from the mucosal extract of a subject with Leber's hereditary optic neuropathy was added to that of a control sample but had no effect on the enzyme activity.

The mean (SEM) activity of rhodanese in rectal mucosa and liver obtained at necropsy was $198(41.9) \mu \mathrm{mol}$ thiocyanate $/ \mathrm{g}$ protein $/ \mathrm{min}(\mathrm{n}=11)$ and $4712(205 \cdot 6) \mu \mathrm{mol}$ thiocyanate/g protein $/ \min (n=8)$, respectively.

\section{Discussion}

The finding of reduced rhodanese activity in the rectal mucosa of subjects with Leber's hereditary optic neuropathy substantiates the report of Cagianut $e t$ al of such a reduction in the livers of two patients with this neuropathy. ${ }^{5}$ This supports earlier evidence suggesting an inborn error of cyanide detoxication in this condition.

The sixfold reduction in the activity of rhodanese in rectal mucosa found in this study is also similar in magnitude to the reduction in hepatic tissue reported by Cagianut et al. The recent report of normal rhodanese activity in the anterior tibial muscle of subjects with Leber's hereditary optic neuropathy ${ }^{9}$ does not detract from our findings as there may be tissue specific isoenzymes of rhodanese. Defective enzyme activity may be expressed only in the rectal mucosa, hepatic tissue, and optic nerve. It is therefore important to measure the activity of rhodanese in optic nerves as well as performing family studies of rhodanese activity.

In a matroclinally inherited disease such as Leber's hereditary optic neuropathy all the offspring of a carrier woman are at risk of developing the disease. When advice is given the hazards of smoking cigarettes and ingesting dietary cyanogenetic substances, such as almonds, beans, peas, and cassava, need to be explained to patients and their relatives.

We thank Professor W I McDonald, Dr R W Ross Russell, Mr M D Sanders, and $\mathrm{Dr} J$ Wilson for providing access to patients under their care. We thank Dr C B Williams and Mr A E Thompson for supplying the control specimens. This study was approved by the ethics committee at St Thomas's Hospital.

\section{References}

1 Wilson J. Leber's hereditary optic atrophy: a possible defect of cyanide metabolism. Clin Sc 1965;29:505-15

2 Wilson J, Linnell JC, Mathews DM. Plasma cobalamins in neuro-ophthalmological diseases. Lancet 1971;i:259-61.

3 Wilson J. Cyanide in human disease: a review of clinical and laboratory evidence. Fundamental Applied Toxicology 1983;3:397-9.

4 Nikoskelainen E, Hoyt WF, Nummelin K. The ophthalmoscopic findings in Leber's hereditary optic neuropathy: II. The fundus findings in the affected family members. Arch Ophthalmo 1983;101:1059-68.

5 Cagianut B, Rhyner K, Furrer W, Schnebli HP. Thiosulphate-sulpher transferase (rhodanese) deficiency in Leber's hereditary optic atrophy. Lancet 1981;ii:981-2.

6 Lundsgaard R. Leber's disease; geneologic, genetic and clinical study of 101 cases of retrobulba optic neuritis in 20 Danish families. Acta Ophthalmol 1944;suppl 21:3-306.

7 Sorbo BH. Crystalline rhodanese 1. Purification and physiocochemical examination. Acta Chem Scand 1955;7:1129-36.

8 Pesce MA, Strande CS. A new micro method for determination of protein in CSF and urine. Clin Chem 1973;19:1265-7.

9 Nikoskelainen E, Hassinen IE, Paljarvi L, Lang H, Kalimo H. Leber's hereditary optic neuroretinopathy, a mitochondrial disease? Lancet 1984;

(Accepted 20 March 1986)

\section{YEARS AGO}

The Russian lady doctors find warm advocates in some of the Moscow journals. The Russkiya Viedomosti, for example, states that they have been most valuable in towns, in the country, and in war. They are very suited for medical duties in girls' schools, and other institutions consisting of female inmates. As in the case of the Zenana mission and similar British institutions, Russian lady-doctors have made themselves very popular amongst the Mahomedans. The writer endeavours to impress upon the St. Petersburg municipal council the importance of subsidising the female medical courses, though other help is also necessary, both from the State and from private munificence. (British Medical Fournal 1886;i:408.) 